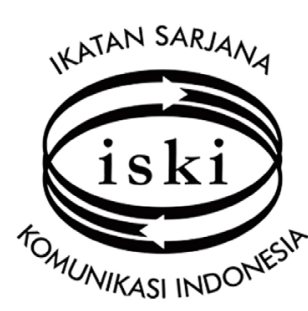

Jurnal Komunikasi. 01 (2016) 48-57

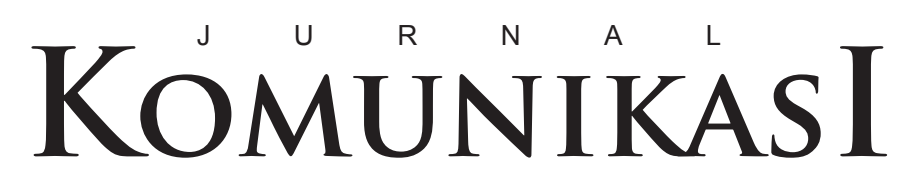

e-ISSN: ---- ---- ---

p-ISSN: ---- ---- ---

IKATAN SARJANA KOMUNIKASI INDONESIA

\title{
CITALINUABDI: UPAYA MEMBANGUN SISTEM INFORMASI DESA YANG BERMAKNA
}

\author{
Nunik Maharani Hartoyo ${ }^{1}$; Ika Merdekawati ${ }^{2}$ \\ ${ }^{1,2}$ Fakultas Ilmu Komunikasi Universitas Padjadjaran

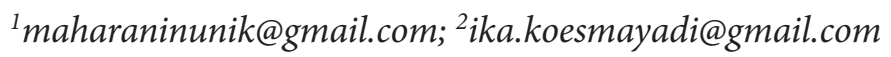

\begin{abstract}
Abstrak:
Undang-Undang Nomor 6 tahun 2014 tentang Desa (UU Desa) mengamanatkan pengembangan sistem informasi desa (SID) demi membuka akses informasi dari dan hingga tingkat desa, yang terhubung/berjaringan secara berjenjang dengan sistem pemerintahan di level nasional. SID diharapkan dapat mendorong kemajuan desa dengan mengoptimalisasikan potensi lokal. Warga Desa Citali, Kecamatan Pamulihan, Kabupaten Sumedang dengan didampingi fasilitator dari tim pengabdian kepada masyarakat Universitas Padjadjaran, memilih memanfaatkan platform blog yang tersedia gratis sebagai upaya persiapan dalam rangka memenuhi amanat UU Desa. Karakteristik warga Desa Citali yang terbuka sekaligus bangga pada identitas desanya tercermin dalam partisipasi aktif sejak proses inisiasi dan pemilihan judul domain yang merepresentasikan identitas mereka. Karakteristik ini pun mengejawantah pada proses perencanaan dan produksi konten SID citalinuabdi. Meski demikian, warga masih menghadapi berbagai kendala. Selain persoalan teknis dan SDM, produksi konten SID belum berjalan lancar sehingga belum mengoptimalisasi potensi lokal dan belum dapat menjawab kebutuhan riil warganya. Di lain pihak, potensi pemanfaatan SID ini akan bersinergi dengan upaya pemerintah untuk mendorong pembentukan dan pemberdayaan Badan Usaha Milik Desa (BUMDes) sebagai salah satu insitusi penggerak potensi ekonomi desa dan berada dalam payung hukum yang sama, yakni UU Desa. Untuk itu, perlu dilakukan upaya strategis dan sistematis untuk menjembatani idealita dan realita melalui kemitraan antar pemangku kepentingan yang berlangsung sinergis dan berkelanjutan.
\end{abstract}

Kata Kunci: literasi media dan informasi, media komunitas, pemberdayaan, Sistem Informasi Desa, UU Desa

\section{PENDAHULUAN}

Setelah melalui proses panjang, UndangUndang Nomor 6 tahun 2014 tentang Desa (UU Desa) akhirnya disahkan pada tanggal 18 Desember 2013. Pengesahan ini diikuti kemudian oleh penandatanganan Peraturan Pemerintah Nomor 43 Tahun 2014 tentang Peraturan Pelaksanaan UndangUndang Nomor 6 Tahun 2014 tentang Desa pada 30 Mei lalu oleh Presiden Susilo Bambang Yudhoyono. UU Desa dan beragam peraturan turunannya mengamanatkan beragam aspek pengelolaan desa yang diharapkan dapat mendorong kemajuan desa dengan mengoptimalisasikan potensi lokal. Dalam bagian ketiga bab IX UU Desa mengenai Pembangunan Desa dan Pembangunan Kawasan
Perdesaan, diamanatkan pengembangan sistem informasi desa (SID) demi membuka akses informasi dari dan hingga tingkat desa. SID ini diharapkan terhubung dengan sistem informasi yang lebih tinggi (Kabupaten/Kota) yang pada gilirannya akan pula terhubung/berjaringan secara berjenjang dengan sistem pemerintahan di level nasional.

Sebagaimana yang diamanatkan dalam pasal 86 ayat 4 UU Desa, SID berisi informasi yang meliputi data Desa, data Pembangunan Desa, Kawasan Perdesaan, serta informasi lain yang berkaitan dengan Pembangunan Desa dan pembangunan Kawasan Perdesaan. UU Desa lebih lanjut mengatur bahwa SID akan dikelola oleh Pemerintah Desa, dan dapat diakses oleh masyarakat Desa beserta semua 
pemangku kepentingan. Ia merupakan sebuah sistem informasi yang menghubungkan antar fungsi pengelolaan data dan informasi secara utuh di lingkup desa. Diharapkan, SID akan berperan sebagai alat olah data dan informasi berbasis TIK yang akan menjadi salah satu rujukan dasar dan pemberi fungsi layanan di tingkat desa yang akan berjalan baik dalam ranah offline maupun online. Pada bentuknya yang offline, SID mengejawantah dalam sebuah jaringan data dan informasi di kantor desa. Pada bentuknya yang online, SID akan terbangun dan terhubung dalam jaringan data dan informasi berbasis internet, yang menghubungkan desa dengan dunia luar.

Gambar 1. Kerangka Kerja Analitis SID

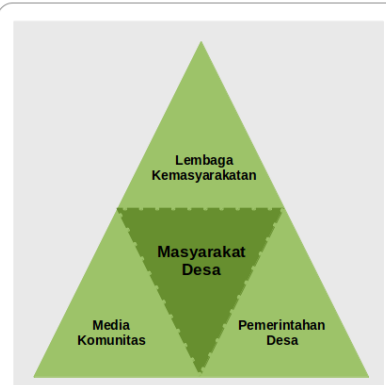

Sistem Informasi Desa (SID)

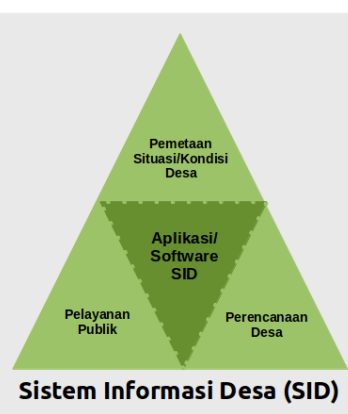

Sumber: (n.d.). SID untuk Pelayanan Publik dan Manajemen Informasi Desa.

Berdasarkan kerangka kerja sebagaimana tergambar dalam ilustrasi di atas, SID yang akan diterapkan di desa-desa dibangun dengan tiga fungsi dasar. Data dan informasi yang terhimpun di dalam sistem ini, paling tidak akan membantu desa untuk melakukan pelayanan publik, perencanaan pembangunan, dan pemetaan situasi untuk pengambilan keputusan secara cepat dan akurat. Dengan teknologi berbasis TIK, diharapkan ketiga aspek fungsi SID tersebut tidak terbatas hanya bisa dijalankan di lingkup kantor desa atau desa saja. Bahkan, dengan dukungan teknologi internet, ketiga fungsi itu bisa dilakukan untuk menjangkau khalayak yang lebih luas. Fungsi SID online yang mewujud sebagai website desa adalah bentuk nyata dari layanan tersebut. Dengan website, desa kemudian mampu menyelenggarakan pelayanan publik, perencanaan pembangunan, dan pemetaan situasi secara terbuka dan lebih luas (SID untuk Pelayanan Publik dan Manajemen Informasi Desa).

Ruang lingkup sistem informasi desa paling tidak mencakup dua hal, yakni pelayanan atas data dan informasi desa, serta pelayanan data administratif. Ruang lingkup tersebut berkaitan erat dengan fungsi layanan publik ini dengan SID, yang diatur dalam beberapa perundang-undangan lainnya, seperti Undang-Undang Republik Indonesia Nomor 14 Tahun 2008 tentang Keterbukaan Informasi Publik dan Undang-Undang Republik Indonesia Nomor 11 Tahun 2008 tentang Informasi dan Transaksi Elektronik. SID dengan fungsi olah data dan informasi berbasis komputer semakin mendekatkan desa pada ranah layanan data dan informasi publik dan elektronik, baik dalam bentuknya yang offline maupun online. Selain itu, dengan disahkannya Undang-Undang Republik Indonesia Nomor 6 Tahun 2014 tentang Desa, pemerintahan desa semakin memiliki posisi dan peran strategis dan penting dalam perencanaan kebijakan publik dan pengambilan keputusan. Dengan dukungan SID, pemerintah desa diharapkan juga mampu menjadi pemerintahan yang efektif, efisien, terbuka, dan bertanggung jawab.

Dalam praktiknya, pelaksanaan SID membuka peluang sekaligus tantangan bagi desa. Setidaknya ada dua hal utama yang dapat disoroti, yakni kapasitas sumber daya manusia serta kesiapan dan ketersediaan sarana dan prasarana di tingkat desa. Berkaitan dengan hal ini, kegiatan Pengabdian Kepada Masyarakat (PKM) yang dilaksanakan oleh civitas academica di lingkungan Universitas Padjadjaran dapat berjalan beriringan sehingga dapat memberikan manfaat langsung bagi masyarakat. Lebih jauh, kegiatan PKM yang bersinergi dengan program pemerintah akan memberikan kesempatan bagi civitas academica untuk tidak hanya mengamalkan ilmunya namun sekaligus membuka kesempatan untuk mempertajam dan mengembangkan kompetensi keilmuannya sesuai kebutuhan riil masyarakat.

Sebagai sebuah sistem yang mendorong pemerataan akses informasi dari dan untuk desa, SID harus dapat dimanfaatkan secara optimal baik untuk keperluan internal yang dapat menjawab kebutuhan dan permasalahan masyarakat desa maupun untuk keperluan membuka jejaring eksternal dalam rangka memasarkan dan mengembangkan potensi desa secara lebih luas. Sebagai akibatnya, sumber daya manusia yang akan berperan sebagai pengelola SID tentu tidak hanya dihadapkan pada persoalan penguasaan teknologi, 
namun lebih jauh lagi, pengelola memiliki tanggung jawab untuk memanfaatkan teknologi yang ada demi menyebarkan informasi yang bermanfaat bagi kemaslahatan masyarakat desa. Di sinilah kompetensi mengenai literasi media memainkan peran penting dalam menjembatani persoalan kebutuhan konsumsi dan penyebaran informasi yang bermanfaat bagi masyarakat. Masyarakat yang melek media akan memiliki kemampuan untuk mengakses mediaguna memenuhikebutuhan mereka akan informasi terkait, mampu menerjemahkan isi media sesuai dengan konteks hidup dan kebutuhan lokal, mampu menimbang dan menakar kesahihan informasi yang didapat melalui media serta dapat pula memanfaatkan media untuk menyuarakan kebutuhan sekaligus memasarkan potensi lokal..

Masyarakat yang melek media akan memiliki kemampuan untuk mengakses media guna memenuhi kebutuhan mereka akan informasi terkait, mampu menerjemahkan isi media sesuai dengan konteks hidup dan kebutuhan lokal, mampu menimbang dan menakar kesahihan informasi yang didapatmelalui mediaserta dapat pula memanfaatkan media untuk menyuarakan kebutuhan sekaligus memasarkan potensi lokal. Di sinilah kompetensi SDM pengelola SID mengenai literasi media memainkan peran penting dalam menjembatani persoalan kebutuhan konsumsi dan penyebaran informasi yang bermanfaat bagi masyarakat. Karenanya, literasi media menjadi isu yang relevan untuk menjawab berbagai permasalahan dan tantangan yang ada dalam masyarakat utamanya dalam konteks pengembangan dan pengelolaan SID yang bernilai dan bermakna bagi warganya.

Pemberdayaan masyarakat dan pengembangan kompetensi dalam konteks literasi media menurut Badan PBB, UNESCO, adalah syarat mutlak dalam rangka pemerataan dan memberikan kemudahan akses terhadap informasi dan pengetahuan. Dalam rangka penyadaran literasi informasi dan bermedia, UNESCO (2011) telah menyusun sebuah buku kurikulum tentang pengajaran materi literasi informasi dan media (Media and Information Literacy/ MIL) yang terdiri dari beberapa aspek, sebagai berikut :

Lebih jauh, menurut UNESCO, literasi informasi menekankan pada pentingnya akses kepada informasi dan masalah penggunaan etika dalam informasi, sedangkan literasi media menekankan pada kemampuan untuk memahami fungsi-fungsi media, mengevaluasi bagaimana fungsi-fungsi tersebut berlaku dan bagaimana menggunakan media sebagai bagian dari sarana untuk berekspresi.

\section{PROGRAM PENDAMPINGAN PENGEMBANGAN DAN PENGELOLAAN KONTEN SID}

Sesuai paparan di atas, literasi media dan informasi adalah salah satu kompetensi penting dalam menjawab tantangan jaman. Hal ini tentu juga sejalan dengan semangat UU Desa yang akan segera diaplikasikan. Namun pada praktiknya tidak mudah membangun SID. Temuan dari program pendampingan yang telah dilakukan sebelumnya, penguasaan TIK serta literasi informasi dan media pada aparat desa, maupun simpul-simpul masyarakat desa sangatlah lemah. Selama ini, para aparat desa serta kader masyarakat untuk berbagai program pemerintah seperti kader PKK, Posyandu, kepala dusun, aparat RW, RT, telah terbiasa dengan berbagai kegiatan pengumpulan data dengan instrumen yang telah disiapkan oleh jenjang pemerintahan di atasnya. Namun seringkali terjadi, berbagai data yang mereka kumpulkan tidak sinkron mana kala dipertemukan antara satu data dengan data lainnya. Banyak data dikumpulkan lebih untuk kepentingan tingkat pemerintahan di atas dan belum terasakan langsung manfaatnya oleh masyarakat setempat.

Untuk itu, program pendampingan perlu diarahkan untuk perencanaan pengembangan SID yang memiliki kegunaan nyata bagi seluruh kalangan masyarakat, bukan hanya bagi segelintir elit desa, birokrasi, atau pemerintahan pusat. Sebagai contoh, manakala desa memperoleh kucuran dana pembangunan, masyarakat harus mengetahui dan mengerti serta berpartisipasi dalam proses pembangunan di desanya. Informasi melalui kucuran dana pembangunan serta arah pembangunan desa ini dapat diinformasikan melalui SID, sehingga pembangunan desa dapat berjalan transparan serta melibatkan semua warga tanpa kecuali.

Program pengembangan dan pengelolaan SID Desa Citali mengedepankan pelibatan warga agar mereka mengerti, mau dan mampu menetapkan tujuan bersama sehingga mereka merasa memiliki pusat informasi desa. Dengan keterlibatan masyarakat, diharapkan SID yang dibangun bersama ini akan memiliki manfaat nyata untuk peningkatan kualitas hidup masyarakat setempat. Program ini juga direncanakan untuk menjadi benchmark 


\section{Tabel 1. Elemen Kunci Literasi Media and Informasi Literasi Informasi}

\begin{tabular}{|l|l|l|l|l|l|l|}
\hline $\begin{array}{l}\text { Define and } \\
\text { articulate } \\
\text { information } \\
\text { needs }\end{array}$ & $\begin{array}{l}\text { Locate and } \\
\text { access } \\
\text { information }\end{array}$ & $\begin{array}{l}\text { Assess } \\
\text { information }\end{array}$ & $\begin{array}{l}\text { Organize } \\
\text { information }\end{array}$ & $\begin{array}{l}\text { Make ethical } \\
\text { use of } \\
\text { information }\end{array}$ & $\begin{array}{l}\text { Communicate } \\
\text { information }\end{array}$ & $\begin{array}{l}\text { Use ICT skills } \\
\text { for information } \\
\text { processing }\end{array}$ \\
\hline
\end{tabular}

\section{Literasi Media}

\begin{tabular}{|l|l|l|l|l|}
\hline $\begin{array}{l}\text { Understand } \\
\text { the role and } \\
\text { functions of media } \\
\text { in democratic } \\
\text { societies }\end{array}$ & $\begin{array}{l}\text { Understand the } \\
\text { conditions under } \\
\text { which media can } \\
\text { fulfil their functions }\end{array}$ & $\begin{array}{l}\text { Critically evaluate } \\
\text { media content in } \\
\text { the light of media } \\
\text { functions }\end{array}$ & $\begin{array}{l}\text { Engage with media } \\
\text { for self-expression } \\
\text { and democratic } \\
\text { participation }\end{array}$ & $\begin{array}{l}\text { Review skills } \\
\text { (including ICTs) } \\
\text { needed to produce } \\
\text { user-generated } \\
\text { content }\end{array}$ \\
\hline
\end{tabular}

Sumber: UNESCO (Fadilah, Hartoyo, Yudhapramesti, Herawati, \& Merdekawati, 2014)

\section{Gambar 2. Ruang Lingkup MIL}

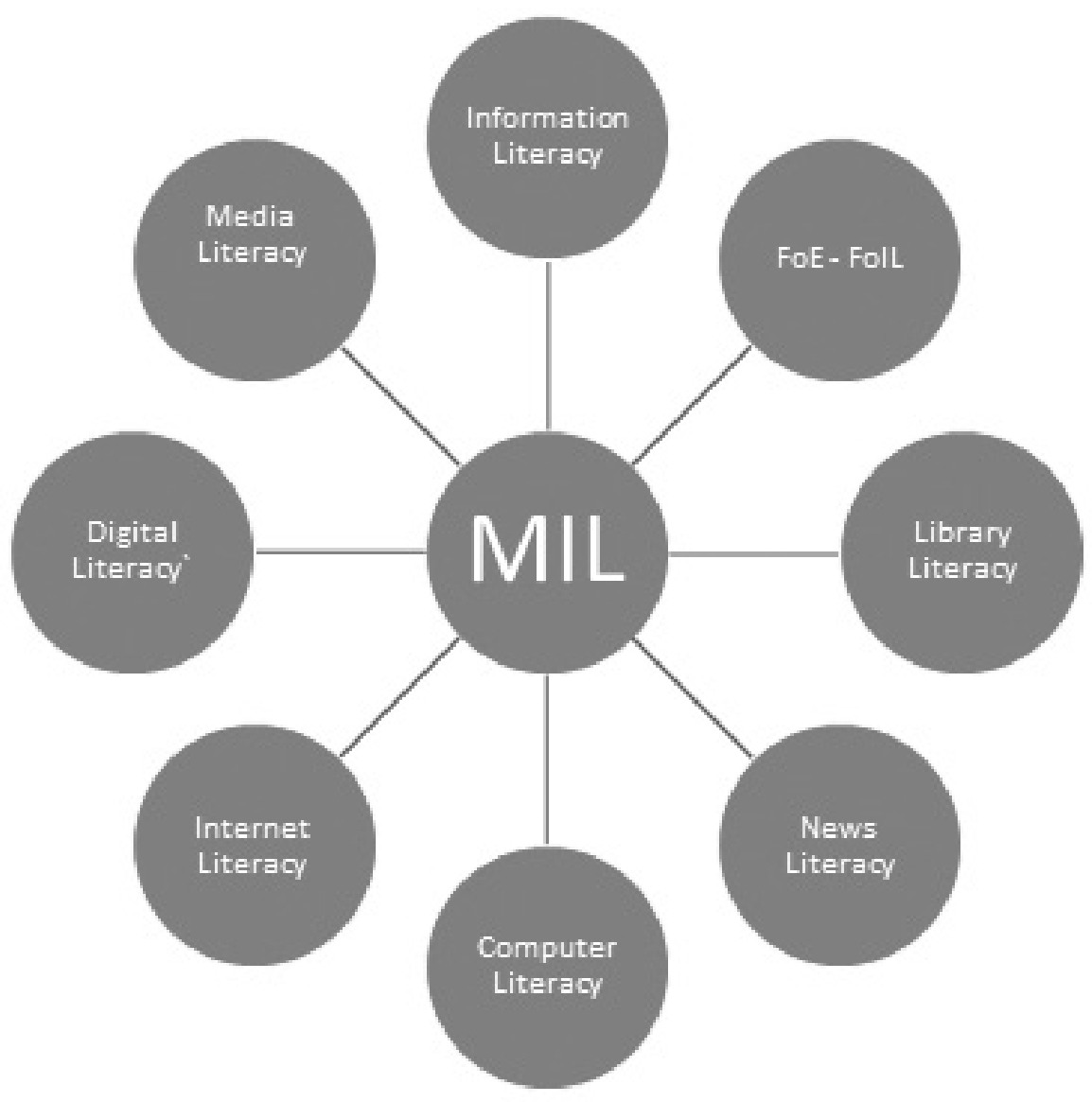

Sumber: UNESCO (Fadilah, Hartoyo, Yudhapramesti, Herawati, \& Merdekawati, 2014) 
yang kelak dapat diikuti oleh desa-desa lain untuk dapat mengembangkan SID yang sesuai dengan kebutuhan masyarakat setempat, dengan tetap mengikuti standard yang ditetapkan oleh tingkat pemerintahan di atasnya.

Pemilihan Desa Citali Kecamatan Pamulihan Kabupaten Sumedang sebagai lokasi kegiatan berdasarkan beberapa pertimbangan. Sebagian wilayah desa ini digunakan sebagai lahan proyek jalan tol Cisumdawu yang akan menghubungkan tol Cileunyi dan tol Trans Jawa di Dawuan. Kondisi ini mengubah tidak hanya bentang alam Desa Citali namun juga berbagai aspek sosial kemasyarakatan lainnya. Pertimbangan kedua adalah kebutuhan riil aparat pemerintahan Desa Citali khususnya dalam pengembangan dan pengelolaan konten Sistem Informasi Desa.

Kehadiran Sistem Informasi Desa berbasis blog yang telah berhasil diinisiasi dalam kegiatan PKM sebelumnya, perlu dikembangkan lebih lanjut agar SID tersebut memiliki nilai dan makna bagi warga desa. Inisiasi blog citalinuabdi.wordpress.com perlu diarahkan pada pembangunan rasa kepemilikan oleh seluruh pemangku kepentingan desa. Dalam kapasistas inilah maka fokus pendampingan kali ini diarahkan pada pengembangan dan pengelolaan konten yang bersifat partisipatoris namun tetap memiliki struktur dan alur produksi yang jelas hingga mampu hadir sebagai sistem informasi rujukan utama bagi warga Desa Citali sendiri serta berfungsi sebagai jendela bagi khalayak di luar Desa Citali untuk mengenal lebih jauh potensi desa dan kehidupan sosial masyarakatnya.

Karena kegiatan ini adalah tindak lanjut dari kegiatan serupa di tahun 2014 , maka fokus bahasan dalam kegiatan pendampingan kali ini adalah pada pengembangan dan pengelolaan konten Sistem Informasi Desa (SID) berbasis blog sebagai upaya mengoptimalisasikan keberadaan blog citalinuabdi. wordpress.com di Desa Citali, Kecamatan Pamulihan, Kabupaten Sumedang.

\section{METODE PEMECAHAN MASALAH}

Sistem Informasi Desa (SID) yang bermakna dan bermanfaat bagi masyarakat Desa baik secara internal maupun eksternal memerlukan tidak hanya dorongan yang bersifat top down. Pengelolaan (SID) yang efektif tentu dimulai dari harapan bahwasanya SID akan membantu menciptakan kehidupan masyarakat yang lebih baik, dan dilakukan sendiri oleh masyarakat. Berdasarkan kerangka pemikiran tersebut, program pendampingan dilakukan untuk mendorong partisipasi masyarakat desa dalam mengelola dan mengembangkan konten SID citalinuabdi.wordpress.com demi pencapaian kemajuan dan kemakmuran desa. Civitas academica akan menjadi fasilitator sekaligus memberikan pendampingan teknis terkait informasi yang diperlukan dalam membangun dan mengelola SID.

Masyarakat akan digerakkan dan didorong agar mampu mengenali dan menggali potensi dirinya. Masyarakat melakukan sendiri kegiatannya mulai dari proses perencanaan sampai pelaksanaan sekaligus mengawasi dan mengevaluasi kegiatan tersebut. Dengan demikian masyarakat harus berani bertindak secara terus menerus untuk memperbaiki kualitas dan taraf hidup dan martabat dirinya, keluarga dan lingkungannya (COREMAP II, 2006).

Posisi dan peran kelompok sasaran di atas sangat signifikan dalam struktur kemasyarakatan di tingkat desa. Mereka merupakan ujung tombak sekaligus katalisator dalam setiap proses pembangunan desa dan dengan sendirinya, kemampuan kelompok sasaran ini dalam hal pengembangan dan pengelolaan konten Sistem Informasi Desa sangat menentukan arah dan keberhasilan program itu sendiri. Adapun kelompok sasaran kegiatan pendampingan ini adalah: Seluruh anggota tim pengelola SID citalinuabdi.wordpress.com; Aparat pemerintahan desa yang terdiri dari Kepala Desa, Sekretaris Desa, Kepala-Kepala Urusan dan anggota Badan Permusyawarahan Desa (BPD); Perwakilan berbagai unsur masyarakat seperti Kader PKK, Kader Posyandu, Kader Karang Taruna dan Tokoh masyarakat/ulama.

\section{HASIL DAN DISKUSI}

Pada prinsipnya, program pendampingan ini adalah muara dari aktualisasi kegiatan pendidikan dan penelitian, penerapan Ilmu Pengetahuan, Teknologi dan Seni secara melembaga kepada masyarakat. Untuk itu, perlu menjalin kerjasama dengan pihak-pihak terkait agar kemandirian dan kesiapan masyarakat dapat bertahan dan program dapat terus dikembangkan. Perlu dibangun keinginan dan motivasi yang kuat untuk mandiri dari masyarakat termasuk dalam hal ini semangat berswadaya. Pengelola SID dan pemangku kepentingan di lingkungan Desa Citali sejak tahun 2013 telah didorong untuk secara aktif berpartisipasi 
untuk menemukan kendalanya sendiri, mengenali potensi dan mampu melakukan evaluasi diri secara proporsional agar penerapan SID akan bermanfaat secara optimal dan mendorong pada kemajuan dan kemakmuran desa. Untuk itu, desain program yang berpusat pada masyarakat diharapkan dapat menumbuhkan rasa memiliki, membangun keinginan dan motivasi yang kuat untuk memaksimalkan SID.

Strategi ini dipilih agar masyarakat Citali dapat melanjutkan dan terus mengembangkan program SID yang berbasis kebutuhan masyarakat-serta sesuai dengan standard yang ditetapkan oleh tingkat pemerintah di atas desa. Dengan peningkatan pemahaman tentang SID, serta peningkatan kemampuan teknis TIK, diharapkan pengelola dapat melanjutkan rencana pengembangan SID secara mandiri.

\section{TENTANG CITALINUABDI.WORDPRESS. COM}

citalinuabdi.wordpress.com adalah sistem informasi desa yang dirintis dan dikembangkan oleh warga Desa Citali dengan pendampingan dari tim Pengabdian Kepada Masyarakat Universitas Padjadjaran. Setelah didahului oleh eksplorasi pemahaman dan kesadaran warga mengenai nilai penting, apa dan mengapa perlu memiliki SID, warga dan pengelola menjalani proses pengambilan kebijakan berdasarkan pertimbangan-pertimbangan tertentu layaknya dalam pengelolaan media. Berikut alur yang dijalankan:

Pemilihan platform SID berbasis internet yang dikombinasikan dengan SID berbasis media tradisional (SMS dan publikasi cetak) berangkat dari kenyataan bahwa masyarakat Desa Citali sebagian besar masih mengandalkan media SID konvensional. Pilihan mengembangkan website desa lebih didorong oleh visi pemanfaatan teknologi Internet dan usaha beradaptasi dengan amanat UU Desa. Sementara itu, pemilihan platform weblog didasari oleh beberapa pertimbangan yang terangkum dalam tabel berikut:

Berdasarkan pertimbangan sebagaimana disebutkan di atas disertai dengan hasil diskusi yang hidup dari warga, maka para calon pengelola weblog Desa Citali secara sadar dan aktif memutuskan untuk menggunakan platform blog wordpress. com. Adapun alamat weblog yang disepakati adalah citalinuabdi.wordpress.com. Pemilihan nama ini telah melalui proses yang cukup intensifkarena warga ingin menunjukkan identitas desa tanpa diintervensi oleh muatan-muatan politis. Nama ini disepakati karena selain mampu menggambarkan kearifan lokal, nama citalinuabdi (Citali milik saya) sekaligus menunjukkan rasa memiliki serta kebanggaan warga. Bersama-sama warga menentukan desain tata letak yang sesuai serta memilih foto yang akan menjadi ciri khas blog desa tersebut.

Terkait ketersediaan sarana dan prasarana, citalinuabdi dibangun berdasarkan semangat belajar. Pemerintahan Desa menghadapi beberapa kendala terkait sarana dan prasarana penunjang seperti ketersediaan koneksi internet yang dapat diandalkan, SDM yang mampu melaksanakan tugas pengelolaan SID secara berkala dan sesuai dengan standar yang telah ditetapkan bersama dengan merujuk pada UU Desa dan peraturan turunannya. Pada tahap awal, tim teknis berfokus pada pembangunan kerangka blog citalinuabdi dengan memperhatikan informasi apa saja yang wajib ada dalam SID serta informasi-informasi relevan lain yang telah diputuskan warga dalam pertemuan sebelumnya. Tim teknis ini didampingi oleh Tim Pendamping dan tenaga pendukung teknis (mahasiswa) dalam mendesain kerangka SID. Hal ini dilakukan agar di masa datang, warga dapat secara mandiri mengembangkan SID dengan pendampingan yang sangat minimal dari Tim Pendamping. Sementara itu, tim konten berfokus pada pembuatan konten yang telah disesuaikan dengan hasilkesepakatan sebelumnya. Tim konten mengaplikasikan konsep $5 \mathrm{~W}+1 \mathrm{H}$ dalam berita-berita desa untuk berikutnya diunggah ke blog desa. Di bagian akhir dilakukan sinkronisasi hasil dan bersama-sama berproses dalam pengunggahan weblog citalinuabdi.wordpress. com sehingga memungkinkan seluruh peserta yang hadir untuk belajar bersama sekaligus memberi masukan dalam pembuatan SID.

\section{PENGELOLAAN SID CITALINUABDI. WORDPRESS.COM SEBAGAI MEDIA KOMUNITAS}

Berdasarkan hasil lokakarya pembuatan konten SID, maka pembuatan blog telah melalui tahap rintisan. Karenanya, agar SID dapat terus dikembangkan, Tim Pendamping dari Universitas Padjadjaran pun menugaskan pada Tim Pengelola SID untuk terus menerus memperbaharui isi, terutama yang berkaitan dengan konten-konten wajib yang selama ini telah dimiliki aparat desa 
Tabel 2. Pertimbangan Pemilihan Platform

\begin{tabular}{|l|l|}
\hline \multicolumn{1}{|c|}{ Website } & \multicolumn{1}{c|}{ Weblog } \\
\hline - Biaya relatif lebih mahal (harus membayar domain) & - Tersedia platform gratis yang dapat dioptimalisasi \\
$\begin{array}{l}\text { - Dapat bergabung menggunakan domain desa.id namun } \\
\text { memiliki implikasi politis. }\end{array}$ & $\begin{array}{l}\text { - Terdapat platform blog yang memudahkan migrasi ke format } \\
\text { web apabila di masa datang warga dan/atau pemerintah } \\
\text { memutuskan untuk menggunakan format website }\end{array}$ \\
$\begin{array}{l}\text { - SDM yang ada harus mampu melakukan hosting secara } \\
\text { mandiri }\end{array}$ & $\begin{array}{l}\text { - SDM dapat mengembangkan platform blog mulai dari desain } \\
\text { dan aplikasi sederhana dan dapat terus diadaptasi seiring } \\
\text { meningkatnya kebutuhan }\end{array}$ \\
\hline
\end{tabular}

Sumber: Luckie dalam Fadilah, Hartoyo, Yudhapramesti, Herawati, \& Merdekawati, 2014

\section{Gambar 3. Alur Kerja Inisiasi Citalinuabdi}

Sumber: Tim Pendamping, Mei-Agustus 2015

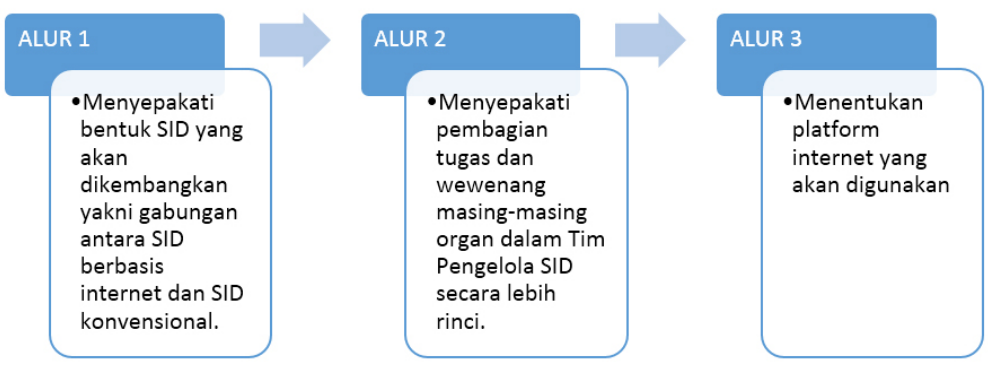

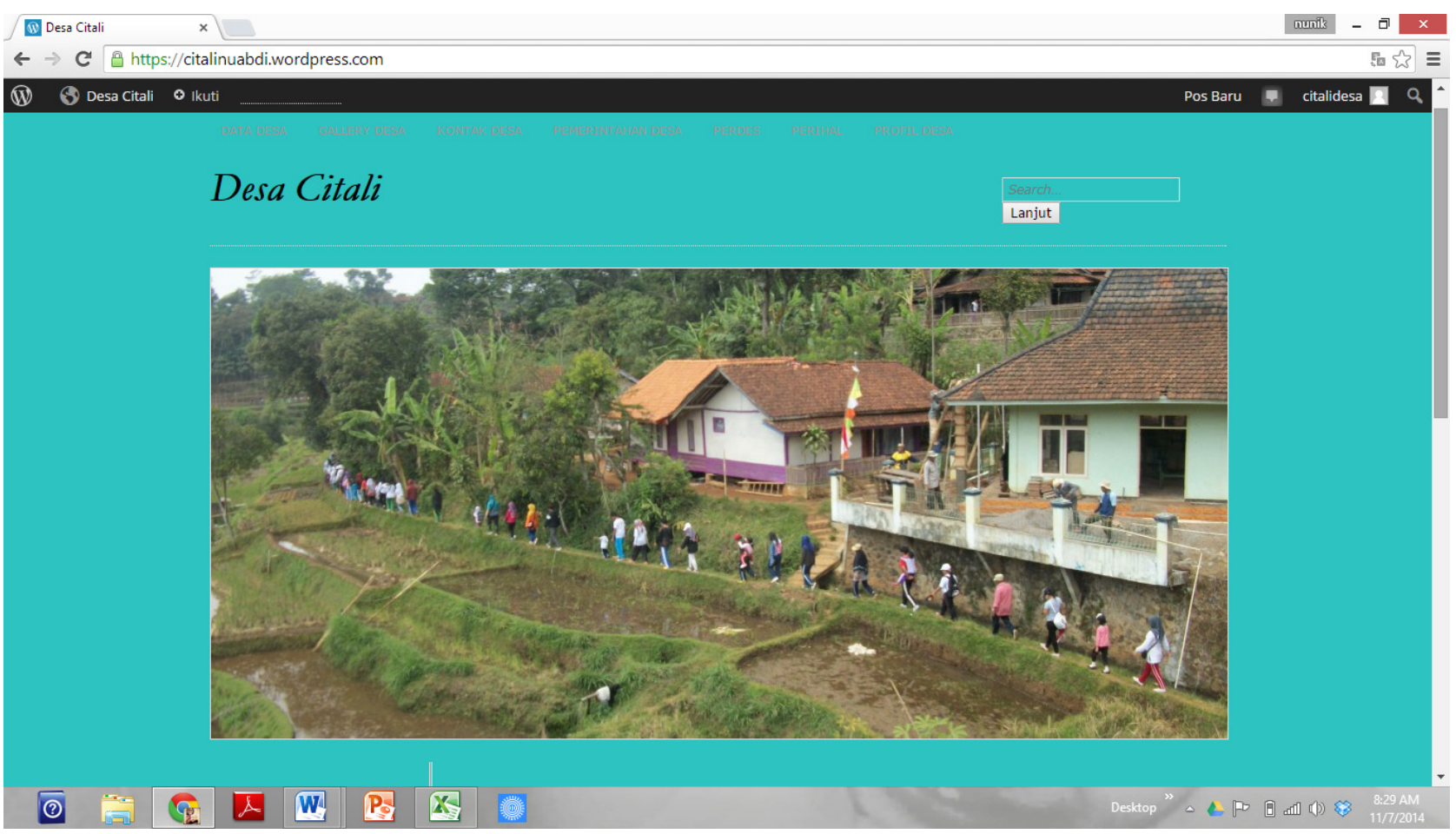

Gambar 4. Laman citalinuabdi.worpress.com

Sumber: Tim Pendamping, 2014- 2015 
namun belum dipublikasikan secara online. Tim Pendamping dalam kegiatan ini melakukan kegiatan monitoring dan evaluasi jarak jauh sebagaimana layaknya konsumen media online. Dengan demikian, Tim Pendamping dapat terus memberikan input dan dorongan untuk memastikan bahwa cikal bakal SID desa Citali dapat terus berkembang, disesuaikan dengan kebutuhan yang ada.

Adapun fokus konten didesain dengan merujuk pada jenis pelayanan publik yang diatur dalam Undang-Undang sebagai berikut: 1. Pelaksanaan pelayanan: olah data dan dokumen dengan aplikasi SID lokal (offline) 2. Pengelolaan pengaduan masyarakat: formulir online di website desa, SMS gateway pada SID online, media komunitas (misal: radio komunitas, kotak surat pengaduan) 3. Pengelolaan informasi: website desa, terhubung dengan media komunitas setempat 4. Pengawasan internal: olah data dan dokumen dengan aplikasi SID lokal (offline) 5. Penyuluhan kepada masyarakat: website desa, terhubung dengan media komunitas setempat. 6. Pelayanan konsultasi: olah data dan dokumen dengan aplikasi SID lokal (offline)

Sebagaimana yang telah dipaparkan sebelumnya, Sistem Informasi Desa (SID) yang bermakna dan bermanfaat bagi masyarakat Desa baik secara internal maupun eksternal memerlukan tidak hanya dorongan yang bersifat top down. Pengelolaan (SID) yang efektif tentu dimulai dari harapan bahwasanya SID akan membantu menciptakan kehidupan masyarakat yang lebih baik, dan dilakukan sendiri oleh masyarakat. Berdasarkan kerangka pemikiran tersebut, Tim Pendamping bersama-sama dengan pengelola SID serta tokoh-tokoh kunci dalam pengelolaan dan pengembangan SID ini mencoba melakukan pemetaan kebutuhan terkait pengelolaan dan pengembangan SID citalinuabdi, merancang strategi pengelolaan dan pengembangan SID serta melakukan workshop pengelolaan dan pengembangan konten SID.

Warga Desa Citali pada tahun 2014 lalu telah memilih memanfaatkan platform web log (biasa disingkat sebagai $b \log$ ) sebagai media berbasis internet yang sesuai dengan kebutuhan pembuatan Sistem Informasi Desa mereka. Pada dasarnya setiap orang dapat memanfaatkan platform blog ini untuk beragam kepentingan: kepentingan pribadi, kepentingan komunitas atau lembaga dan apabila dikelola dengan baik, berpotensi memiliki nilai ekonomis bagi pengelola blog. Melalui blog, khalayak dapat langsung memberikan umpan balik melalui ruang komentar yang tersedia dalam setiap posting (materi yang diunggah). Hal ini tentu memberikan nilai tambah (added value) dalam pengembangan platform blog sebagai media komunitas, yang dalam hal ini adalah warga Desa Citali dan masyarakat umum,

Mempublikasikan informasi dan materi penting melalui blog adalah jembatan yang efektif bagi banyak pihak untuk bertemu dan berinteraksi secara virtual. Apabila sebelumnya pertemuan dengan aparat Desa, atau dengan pihak-pihak lain seperti institusi pemerintahan lainnya, investor, keluarga yang terpisah ruang jarak dan waktu, seringkali terasa sulit dan terbatas, media berbasis internet dapat membantu memecahkan problematika tersebut. Selain itu, sejalan juga dengan rencana pemerintah sebagaimana yang termaktub dalam Peraturan Menteri Desa, Pembangunan Daerah Tertinggal, dan Transmigrasi Republik Indonesia Nomor 4 Tahun 2015 tentang Pendirian, Pengurusan dan Pengelolaan, dan Pembubaran Badan Usaha Milik Desa, untuk menggalakkan dan menggerakkan Badan Usaha Milik Desa (BUMDes), maka pemanfaatan media berbasis internet mampu menawarkan ruang amplifikasi ekonomis atas peluang-peluang bisnis yang dimiliki oleh warga Desa.

Blog juga dapat membangun kedekatan emosional antara pengelola blog dengan warganya (komunitas yang dilayaninya) melalui gaya penulisan yang terkesan akrab dan longgar. Gaya penulisan seperti ini membuka ruang ekspresi bagi kedua belah pihak, yang lagi-lagi pada gilirannya akan memberikan nilai tambah berupa rasa memiliki, rasa menjadi bagian kelompok (esprit de corps) dan membangun suasana interaktif dan partisipatif di antara kedua belah pihak. Nilai tambah ini tentu harus dikelola dengan baik untuk menarik perhatian khalayak serta membangun loyalitas khalayak yang telah mengikuti perkembangan $b$ log.

Keberhasilan sebuah blog tentu dipengaruhi oleh kombinasi beragam faktor (Fadilah \& Hartoyo, 2014). Meski demikian, faktor yang dipandang paling penting dalam keberhasilan blog adalah materi yang disajikan. Khalayak pembaca tertarik membaca sebuah blog karena daya tarik konten. Karenanya, tema yang dipilih oleh pengelola blog haruslah tema yang relevan, tidak hanya relevan dengan tujuan pembuatan blognya, namun juga harus relevan dengan minat dan kebutuhan khalayaknya. Karenanya, unique selling point dari 
konten yang ditawarkan oleh pengelola blog kepada khalayak yang dilayaninya harus dapat ditonjolkan, dijaga dan dikembangkan.

Selain itu, dalam pengelolaan blog perlu mempertimbangkan rencana pengembangan dan ruang eksplorasi lebih lanjut. Karenanya, pengelolaan dan pengembangan blog memerlukan komitmen dan stamina. Pilihan tema materi yang diunggah dan gaya penulisan menjadi hal kunci dalam menjaring dan mempertahankan khalayaknya. Frekuensi pembaruan materi secara berkala juga menjadi pertimbangan penting lain. Materi yang ketinggalan jaman atau materi yang tidak pernah diperbaharui baik isi maupun jumlahnya, tentu akan ditinggalkan oleh khalayak.

Lebih dari itu, blog juga menawarkan ruang interaksi di antara pengelola dengan khalayak, atau bahkan interaksi anat khalayak itu sendiri. Blog yang berhasil biasanya mampu membangin komunikasi virtual dan mendorong interaksi antar khalayak dengan melempar pertanyaan dan mendorong agar khalayak memberikan umpan balik. Interaktivitas dan kolaborasi adalah dua hal yang menonjol yang mampu ditawarkan oleh media berbasis internet, termasuk di dalamnya $b \log$. Ruang interaksi ini biasanya diberikan selain melalui kolom komentar, juga dimungkinkan melalui ruang interaksi berbasis teknologi komunikasi lainnya seperti melalui alamat email pengelola, alamat pengelola dan/atau nomor telepon yang dapat dihubungi. Apabila interaksi dapat terfasilitasi dengan baik, maka hasil interaksi kemudian dapat digunakan untuk mengenali lebih jauh karakteristik khalayak, baik itu karakteristik demografis maupun psikografis. Informasi mengenai karakteristik ini penting untuk dimanfaatkan dalam rencana pengembangan konten blog di masa yang akan datang.

Berdasarkan pemaparan tersebut, dalam program pendampingan kali ini, Tim Pendamping lebih banyak mengambil peran sebagai fasilitator. Agar blog citalinuabdi dapat memberikan manfaat optimal dan menjad media yang bermakna bagi warga Desa Citali, maka peran pengelola blog citalinuabdi beserta tokoh-tokoh kunci dalam kehidupan sosial masyarakat desa akan didorong untuk lebih aktif dalam proses pemetaan dan workshop. Posisi ini dipilih Tim Pendamping untuk mendorong partisipasi warga agar lebih terlibat, merasa memiliki dan mampu mengambil manfaat serta mengoptimalkan kesempatan yang ada untuk membangun SID yang sesuai dengan kebutuhan riil warga.
Meski demikian, pada praktiknya Tim Pengelola SID belum mampu menjalankan SID rintisan secara mandiri. Satu tahun pasca program pndampingan SID rintisan ini berlalu, belum ada penambahan konten yang dapat dilihat di laman citalinuabdi. wordpress.com. Dapat diidentifikasi beberapa kendala yang menyebabkan kemandegan proses pengembangan SID rintisan sebagai berikut: Tim Pengelola SID yang sifatnya sukarela belum dapat memberikan komitmen sepenuhnya untuk turut mengembangkan SID dan memperbarui kontennya secara berkala. Proses pembangunan jalan tol Cisumdawu kini telah membelah desa menjadi 2 bagian anmun belum rampung, mempersulit akses warga ke jalan utama non tol sehingga jarak tempuh warga untuk melaksanakan aktivitas sehariharinya memerlukan upaya yang lebih keras. Proses politik di Desa Citali yang tengah mengalami proses pemilihan Kepala Desa turut pula mempengaruhi kinerja Tim Pengelola SID. Akses internet yang kurang baik di wilayah Desa Citali

Kendala-kendala tersebut telah membuat citalinuabdi.wordpress.com belum dapat beroperasi sebagaimana yang dicita-citakan. Diharapkan, perubahan suasana politik pasca pemilihan Kepala Desa mampu memberikan gairah baru bagi pengelola SID dalam mengembangkan dan mengelola citalinuabdi. Peluang lain yang dapat turut dimanfaatkan sebagai momentum pengembangan dan pengelolaan SID ini adalah dengan adanya upaya pemerintah untuk mendorong pembentukan dan pemberdayaan Badan Usaha Milik Desa (BUMDes) sebagai salah satu insitusi penggerak potensi ekonomi desa dan berada dalam payung hukum yang sama, yakni UU Desa. Untuk itu, perlu dilakukan upaya strategis dan sistematis untuk menjembatani idealita dan realita melalui kemitraan antar pemangku kepentingan yang berlangsung sinergis dan berkelanjutan.

\section{SIMPULAN}

Undang-Undang Nomor 6 tahun 2014 tentang Desa (UU Desa) mengamanatkan pengembangan sistem informasi desa (SID) demi membuka akses informasi dari dan hingga tingkat desa, yang terhubung/berjaringan secara berjenjang dengan sistem pemerintahan di level nasional. SID citalinuabdi yang telah dirintis sejak tahun 2014 lalu diharapkan dapat berkontribusi dalam mendorong kemajuan desa dengan mengoptimalisasikan potensi 
lokal. Warga Desa Citali, Kecamatan Pamulihan, Kabupaten Sumedang dengan didampingi fasilitator dari tim pengabdian kepada masyarakat Universitas Padjadjaran, memilih memanfaatkan platform blog yang tersedia gratis sebagai upaya persiapan dalam rangka memenuhi amanat UU Desa.

Dalam kerangka pemikiran tersebut, program pendampingan masyarakat didesain untuk memetakan kebutuhan SDM dan sarana pendukung untuk rencana pengembangan dan pengelolaan konten SID. Adapun fokus program pendampingan terbagi dalam 3 hal, yakni (1) memetakan kondisi sarana dan prasarana pendukung SID yang telah tersedia maupun yang perlu disediakan dalam konteks pengembangan dan pengelolaan konten, (2) Meningkatkan pengetahuan teknis dan nonteknis terkait pengelolaan dan pengembangan konten SID citalinuabdi.wordpress.com melalui workshop, (3) Memiliki rencana pengelolaan dan pengembangan konten SID citalinuabdi.wordpress.com.

Hasil kegiatan menunjukkan bahwa secara umum warga telah merintis upaya pengelolaan dan pengembangan SID sebagai salah satu amanat UU Desa yang akan segera diberlakukan. Meski demikian, pengelola SID yang telah terbentuk belum bekerja optimal karena hambatan sarana, prasarana dan kondisi sosial kemasyarakatan desa yang tengah dalam proses Pemilihan Kepala Desa. Selain itu, basis masyarakat yang masih jauh dari melek internet serta masalah SDM yang terbatas juga turut menjadi faktor belum dikembangkannya SID berbasis internet di Desa Citali.

Lebih lanjut, warga telah menyepakati informasi apa saja yang mereka perlukan, dan mengidentifikasi beberapa informasi penting lain yang perlu ada dalam SID, seperti informasi kesehatan, ekonomi, sosial kemasyarakatan termasuk di dalamnya hukum waris dan pertanahan, pendidikan dan lain sebagainya. Agar bermanfaat dan bermakna bagi warga Citali, SID yang telah ada perlu dikembangkan dengan strategi pendampingan dan pelatihan seperto pelatihan keorganisasian, pendampingan dan pelatihan teknis pengelolaan dan pengembangan konten SID, pelatihan pemanfaatan media dan juga pelatihan etika dan hukun media massa online. Selain itu, pengelola SID juga perlu membangun jejaring dengan Dinas Kominfo Sumedang, lembaga dan desa lain yang telah berhasil mengembangkan SID berbasis internet serta dengan instansi-instansi lain yang relevan.

\section{DAFTAR PUSTAKA}

coremap Ii, S. R. (2006). Panduan Pengambilan Data Dengan Metode Rapid Rural Appraisal (Rra) Dan Participatory Rural Appraisal (Pra), Volume 2. Jakarta: Satker Rehabilitasi Dan Pengelolaan Terumbu Karang (Coremap Ii).

Fadilah, E., \& Hartoyo, N. M. (2014, November). Manajemen Pengembangan Blog Sebagai Media Jurnalistik. Bahan Ajar Manajemen Media. Jatinangor, Indonesia: Lembaga Penelitian, Pengabdian Kepada Masyarakat Dan Penerbitan (Lp3) Fakultas Ilmu Komunikasi Universitas Padjadjaran.

Fadilah, E., Hartoyo, N. M., Yudhapramesti, P., Herawati, M., \& Merdekawati, I. (2014). Kolaborasi Dan Keterlibatan Aktif Warga Desa Dalam Program Pengembangan Sistem Informasi Desa Berbasis Website Di Desa Citali Kecamatan Pamulihan Kabupaten Sumedang Jawa Barat. Prosiding Conference On Communication, Culture And Media Studies 2014 (Pp. 233-242). Yogyakarta: Uii.

(n.d.). SID untuk Pelayanan Publik dan Manajemen Informasi Desa.

Undang-Undang Republik Indonesia Nomor 6 Tahun 2014 tentang Desa

Undang-Undang Republik Indonesia Nomor 14 Tahun 2008 tentang Keterbukaan Informasi Publik

Undang-Undang Republik Indonesia Nomor 11 Tahun 2008 tentang Informasi dan Transaksi Elektronik

Peraturan Pemerintah Nomor 43 Tahun 2014 tentang Peraturan Pelaksanaan Undang-Undang Nomor 6 Tahun 2014 tentang Desa

Peraturan Menteri Desa, Pembangunan Daerah Tertinggal, dan Transmigrasi Republik Indonesia Nomor 4 Tahun 2015 tentang Pendirian, Pengurusan dan Pengelolaan, dan Pembubaran Badan Usaha Milik Desa 